\title{
ANTECEDENTS OF INTERPERSONAL COMMUNICATION MOTIVES ON TWITTER: LONELINESS AND LIFE SATISFACTION
}

\author{
Yoosun Hwang \\ Joongbu University \\ 201 Daehakro Chubumyeon Geumsangun Chungnam South Korea \\ yshwang@joongbu.ac.kr
}

\begin{abstract}
As the sharp distinction between face-to-face communication and mediated interpersonal communication is disappearing, Twitter is now being used for private and public exchanges. This study aims to explore interpersonal communication motives on Twitter in relation to individuals' social psychological states of loneliness and life satisfaction. Social compensation and social-enhancement hypotheses were considered for the theoretical background. Data were gathered from Twitter users through online surveys. Hierarchical regression analyses on each communication motive on Twitter (pleasure, affection, inclusion, escape, relaxation, and control) were performed. Results revealed that loneliness negatively affected the motives of pleasure and affection, while life satisfaction positively affected the motives of pleasure, affection, relaxation, and control. The implications of these findings and the meaning of Twitter for interpersonal communication are discussed.
\end{abstract}

Keywords: Interpersonal Communication Motives, Loneliness, Life Satisfaction, Twitter 


\section{INTRODUCTION}

The development of information communication technologies (ICT) allows people to more efficiently satisfy their need for communication. As social interaction is the innate desire of individuals (Schutz, 1966), various interpersonal communication media are now widely used to maintain personal relationships across offline and online settings. The prevalence of Internet and digital mobile devices has expanded the area of mediated interpersonal communication. In this environment, people continue to maintain their personal relationships in online settings.

In particular, Twitter, a micro-blog that allows short message "tweets" of fewer than 140 characters, now has a global reach and about fifty million users. Twitter provides diverse types and opportunities of communication. First, one function of Twitter, RT (retweet) enables users to disseminate a tweet to all of their "followers" (their Twitter "friends") at once, which facilitates an efficient flow of information. Second, along with this communication to a group, the exchange of conversations between individuals also takes place on Twitter, making it a channel for both public and private interaction. However, personal relationships formed on Twitter are not always reciprocal. People can form unreciprocated relationships with whomever they want, unless the person's Twitter account is private. Ending a relationship is as simple as starting a personal connection. The size of the interpersonal network, i.e., the number of followers, does not always imply the same amount of intimate personal relationship on Twitter. Personal networks formed on Twitter include both private and official relationships; thus, it is assumed that the users may have diverse interpersonal communication motives.

The current study focuses on how individuals' interpersonal relationships and social psychological status are related to interpersonal communication motives on Twitter. Interactions on Twitter can be regarded as a part of an individual's social life and can be related to their patterns of communication in the offline world. It has been supported that personal exchanges through interpersonal communication media have become more entwined with interpersonal relationships in real-life settings (Barnes, 2003). Previously, studies have explored relationships between people's offline and online communication (e.g., Kraut et al., 2002; Mesch, 2001). It has been also verified that individuals' personal traits were associated with the use of interpersonal media (Correa, Hinsley, \& de Zuniga, 2010; Rau, Gao, \& Ding, 2008) and the pattern of interpersonal communication (Prinstein, Boergers, \& Vernberg, 2001). Thus, it can be inferred that the characteristics of one's interpersonal relationships and social psychological status may be reflected in 
his/her online communication.

As Twitter includes various types of personal relationships and interactions, understanding who uses Twitter and for what purpose can provide an insight into the consequences recent interpersonal media have on communication. This functional approach helps to account for the reason and the mechanism behind the process of interpersonal communication (Step \& Finucane, 2002). By doing so, especially in the current study, the kind of interpersonal needs that the interpersonal media can gratify during social interactions is estimated. Also, the direction of the development of interpersonal media can be considered.

\section{LITERATURE REVIEW}

\section{Interpersonal Communication Motives}

Interpersonal communication motives (ICMs) originate from the perspective that people have a basic need for social interaction and they desire to form proper relationships (Schutz, 1966). Based on Schutz's FIRO-B (Fundamental Interpersonal Relations Orientation-Behavior) scale and the uses and gratifications approach (Katz, Blumler, \& Gurevich, 1974), Rubin, Perse, and Barbato (1988) identify six interpersonal communication motives: (1) pleasure, the need to have fun; (2) affection, or the need to exchange care and concern; (3) inclusion, the need to be part of a group or to include others in a group; (4) escape, the need to take one's mind off of certain tasks; (5) relaxation, the need to relieve stress; and (6) control, the desire to dominate others.

Individuals' ICMs have been found to be different depending on their personal and interactional situations. Studies found that ICMs vary with demographic traits, including age (Downs \& Javidi, 1990; Rubin et al., 1988), gender (Barbato \& Perse, 1992; Rubin et al., 1988), and level of education (Rubin et al., 1988). Personal dispositions, such as extroversion, neuroticism, and psychoticism, have been found to have different effects on ICMs (Paulsel \& Mottet, 2004). Communication environments were also found to affect individuals' communication motives (Anderson \& Martin, 1995; Martin, Myers, \& Mottet, 1999). Concerning communicative behaviors, effectiveness of communication (Hullman, 2004), depth and breadth of communication (Graham, Barbato, \& Perse, 1993), and conversational orientations (Barbato, Graham, \& Perse, 2003) were known to form connections with ICMs. As these previous studies show, people tend to have different ICMs depending on their personal and communication environments. 


\section{Twitter and Various Purposes of Communication}

Though ICMs were originally developed in the context of face-to-face (FTF) communication, they are relevant to mediated communication settings. As Schutz (1966) suggests, people have interpersonal needs that can be gratified through sufficient social interaction. Likewise, people perform specific communication behaviors to satisfy their interpersonal motives (Rubin \& Windahl, 1986), and their use of interpersonal media can also be explained by their communication motives (Katz, Blumler, \& Gurevich, 1974). Westmyer, DiCioccio, and Rubin (1998) have found that people select different interpersonal channels (e.g., FTF, telephone, fax, email) to gratify their individual ICMs. People choose a proper medium to satisfy a specific ICM and recognize different ICMs under each interpersonal setting of various media. In other words, in one's day-to-day social life, a person may experience interpersonal needs that can develop into communication motivations for using interpersonal media.

Interpersonal media have provided people with virtual spaces to continue their social interactions. For example, people use social network sites (SNSs) to maintain offline connections in an online space and form an online community by manipulating the list of friends and constructing a profile page (boyd \& Ellison, 2007). Previous studies have found that individuals make use of SNSs for the maintenance and extension of interpersonal relationships (Quan-Haase \& Young, 2010; Raacke \& Bonds-Raacke, 2008; Subrahmanyam, Reich, Waechter, \& Espinoza, 2008). However, the relationships described as "friends" in these virtual spaces do not necessarily mean friendship in real life (boyd, 2006).

In particular, Twitter does not always function as a virtual space for intimate personal community and interpersonal bonds. People use Twitter in order to deliver public information as well as reveal personal updates (Naaman, Boase, \& Lai, 2010). Because people use Twitter as an information hub to diffuse and to receive information in real time, the frequency of tweets increases during an occurrence of a social issue (Hughes \& Palen, 2009; Young, 2008). Through Twitter, users interact not only with their acquaintances but also with people they do not know. Twitter users exchange messages or information even with people they have never met before. However, scholars found that Twitter users primarily interact with personal connections who are friends that they know in their daily lives, regardless of the size of followers on Twitter (Huberman, Romero, \& Wu, 2008). Considering these various types of uses, Twitter seems to play a role in both personal and mass media. Thus, a range of interactions and personal 
relationships may occur, and the users' diverse communication motives may be reflected in it.

\section{Offline Communication and Interpersonal Media Use}

Individuals' media use has been found to be related to interpersonal relationships and interactions in offline settings. Previous studies have investigated two competing hypotheses: social compensation ("Poor get richer") and social enhancement ("Rich get richer"). The first argues that people with less satisfactory offline relationships compensate for them during online interactions (Valkenburg, Schouten, \& Peter, 2005). Interpersonal media are alternatives for deficient social interactions, and those who lack sufficient social interactions seek to gratify unsatisfied interpersonal needs through mediated communication (Papacharissi \& Rubin, 2000). Adolescents who have few friends and feel isolated try to make friends by using the Internet more frequently (Mesch, 2001). The second hypothesis posits that people with sufficient social networks enhance their social interactions through online communication (Valkenburg et al., 2005). People lean on the technological capability of interpersonal media to maintain or to enlarge the scale of their social interactions (Birnholtz, 2010).

However, rather than strictly divide these two types of relationships between offline and online communication, the hypotheses can be considered with the individuals' personal characteristics. Kraut and colleagues (2002) found that Internet use positively affected individuals' involvement in various communication behaviors and emphasized an interaction effect of personal traits such as extroversion and introversion. Those more extroverted and with higher self-esteem were found to be popular during both offline and online interactions, which supports the social-enhancement hypothesis, while people who are more introverted and have lower self-esteem tend to seek popularity on Facebook, which supports the social-compensation hypothesis (Zywica \& Danowski, 2008). Similarly, people who are extroverted are likely to maintain a larger online interpersonal network and spend more time using Facebook (Acar, 2008). Adolescents with a higher level of social anxiety reveal more active online interactions, supporting the social-compensation hypothesis (Campbell, Cumming, \& Hughes, 2006; Desjarlais \& Willoughby, 2010).

Considering these findings, it can be inferred that people with diverse characteristics may have different purposes for using interpersonal media to satisfy their interpersonal communication needs. They seek either to enrich their interpersonal networks or to 
compensate for insufficient interpersonal communication. In each condition, individuals have relevant communication motives for using interpersonal media; hence, the current study focuses on the influence of individuals' social psychological status, such as loneliness and life satisfaction, on the communication motives on Twitter. These two elements represent individuals' contradictory social psychological statuses: Life satisfaction decreases as loneliness increases (Civitci \& Civitci, 2009), and a lower level of life satisfaction is associated with a higher level of loneliness (Neto \& Barros, 2000).

\section{Loneliness and Life Satisfaction as Conditions of Mediated Communication on Twitter}

Loneliness is widely seen as being linked to interpersonal social activities. It has been defined as an unpleasant experience caused by deficiencies in social relationships (Marangoni \& Ickes, 1989; Perlman \& Peplau, 1981). A discrepancy between expected and actual social relationships can be the reason for loneliness (Peplau \& Perlman, 1982). As the social-compensation hypothesis suggests, lonely people lacking interpersonal interactions in real-life tend to use electronic media more frequently (Perse \& Rubin, 1990). Loneliness caused by unfulfilled interpersonal communication needs can affect individuals' patterns of using interpersonal media and be significantly related to their communication motives.

Among interpersonal media, Twitter does not always provide opportunities for intimate personal relationships. Rather, both official information exchanges and private conversations occur as in the offline world. In FTF settings, a negative relationship has been found between loneliness and ICMs of pleasure, affection, and relaxation (Hosman, 1991). Likewise, loneliness is inversely associated with perceived communication satisfaction (Zakahi, 1986). The following hypotheses can be drawn.

H1-1: Loneliness of Twitter users will negatively affect their communication motive of pleasure.

H1-2: Loneliness of Twitter users will negatively affect their communication motive of affection.

H1-3: Loneliness of Twitter users will negatively affect their communication motive of relaxation.

Internet-based interactions have been found to be linked with decreased loneliness and depression (Shaw \& Gant, 2002). Thus, lonely students who have few close friends communicate more frequently with strangers using instant messenger (Gross, Juvonen, \& 
Gable, 2002), and lonely people are more likely to use the Internet to seek companionship than those who are not lonely (Bardi \& Brady, 2010; Wang \& Sun, 2009). They tend to pursue emotional support from others via the Internet (Morahan-Martin \& Schumacher, 2003).

H1-4: Loneliness of Twitter users will positively affect their communication motive of inclusion.

Morahan-Martin and Schumacher (2003) assert that lonely people believe that they can control interpersonal interactions during mediated communication. Lonely adolescents tend to consider Internet communication to be more controllable as well as reciprocal (Peter \& Valkenburg, 2006). Among elders, a feeling of loneliness was related to the communication motive for control (Downs \& Javidi, 1990).

H1-5: Loneliness of Twitter users will positively affect their communication motive of control.

Lonely people tend to participate less in interpersonal communication (Perse \& Rubin, 1990) and have more communication apprehension (Downs, Javidi, \& Nussbaum, 1987). Moreover, lonely people, especially the elderly, have been found to be motivated by the need to escape (Downs \& Javidi, 1990). It is possible that individuals with a higher level of loneliness would consider Twitter as another place to escape real life and to find new companionship.

H1-6: Loneliness of Twitter users will positively affect their communication motive of escape.

Life satisfaction refers to a cognitive judgment about one's life in comparison with an appropriate standard (Diener, Emmons, Larsen, \& Griffin, 1985) and is one component of subjective well-being that causes people to evaluate their lives positively (Diener, 2009; Diener, Emmons, Larsen, \& Griffin, 1985; Diener, Oishi, \& Lucas, 2003). Life satisfaction is interwoven with a society in which people participate and communicate with one another (Diener \& Suh, 1998; Diener, Oishi, \& Lucas, 2003). Individuals' social ties relate to their life satisfaction (Kahneman \& Krueger, 2006), and the level of life satisfaction is associated with the types of interpersonal relationships and the sources of social support (Wan, Jaccard, \& Ramey, 1996).

As such, life satisfaction includes individuals' experimental cognition regarding their active social interactions and intimate personal relationships. For example, close interpersonal relationships with greater intimacy, passion, and commitment help to raise the perception of life satisfaction (Ali \& Chamorro-Premuzic, 2010; Arrindell \& Luteijn, 
2000). Rubin and Rubin (1992) found that people with life satisfaction tend to communicate with others for the reason of pleasure, affection, and relaxation. Elderly people with a high level of life satisfaction reported that they pursued pleasure and affection during interpersonal communication (Barbato \& Perse, 1992).

H2-1: Life satisfaction of Twitter users will positively affect their communication motive of pleasure.

H2-2: Life satisfaction of Twitter users will positively affect their communication motive of affection.

H2-3: Life satisfaction of Twitter users will positively affect their communication motive of relaxation.

As the social-enhancement hypothesis suggests, Twitter users' active social interactions and their interpersonal networks may well be reflected in their online communication. Many studies have revealed a positive relationship between frequent social activities and life-satisfaction (e.g., Bradburn, 1969; Edwards \& Klemmack, 1973; Knapp, 1976). Adolescents with greater life satisfaction maintain more positive personal relationships with their peer groups and parents (Gilman \& Huebner, 2006). In this sense, life satisfaction can be considered to be one of the important elements for psychological and social development (Civitci \& Civitci, 2009), so people with life satisfaction would continue their positive relationships and participate in the online interactions through Twitter.

H2-4: Life satisfaction of Twitter users will positively affect their communication motive of inclusion.

H2-5: Life satisfaction of Twitter users will negatively affect their communication motive of escape.

Previous studies have found that people who feel confident achieve what they want and perceive a higher level of life satisfaction (Lent et al., 2005; Luszczynska, Scholz \& Schwarzer, 2005). Among students, social self-efficacy, or their self-evaluation of their ability to perform social interactions, was found to raise their life satisfaction (Fogle, Huebner, \& Laughlin, 2002). Individuals with higher self-efficacy tend to perceive that they can exert power over communication environments (Hopf \& Colby, 1992) and produce desired outcomes by behaving relevantly during interpersonal communication (Makoul \& Roloff, 1998). From these findings, it can be inferred that people with self-efficacy who feel higher life satisfaction would believe that they can manage personal relationships on Twitter and thus perceive the communication motive of control. 
Based on the rationale, the following hypothesis was drawn.

H2-6: Life satisfaction of Twitter users will positively affect their communication motive of control.

\section{METHOD}

\section{Participants}

To obtain data, an online survey was conducted from October 21 to November 2, 2010 , by a research company. The company conducted the online survey on its nationwide panel group whose size is about 100,000. For the present study, approximately 9,000 panel members were randomly contacted via email and asked to participate in this survey. Thus, a simple random sampling method was employed among the panel members possessed by the company. If the contacted panel members agreed to participate, they were asked to provide basic demographic information. At the beginning of the questionnaire, respondents were asked to indicate whether they use Twitter. Only the Twitter users were allowed to continue the survey. Among the participants, those who completed the questionnaires honestly received some points that could be exchanged for cash. Such a reward was effective to reduce fatigue and insincere attitudes during the survey.

In total, 318 respondents participated in the online survey. Of them, $203(63.8 \%)$ were male, and $115(36.2 \%)$ were female. Their mean age was $33.86(S D=8.76)$ and their age range was 20 to 59. The number of respondents who had completed only junior high school was $1(0.3 \%)$, while $40(12.6 \%)$ had completed only high school. The number of respondents enrolled as undergrad students was 49 (15.4\%). A total of 211 $(66.4 \%)$ of the respondents had undergraduate degrees, and $17(5.3 \%)$ had graduate degrees.

\section{Measure}

Interpersonal communication motives. The scale of interpersonal communication motives (Rubin, Perse, \& Barbato, 1988) was adopted and as Rubin et al. (1988) suggested, the first three items of each six ICM were used. Eighteen items were measured by a 5-point Likert-scale and the reliability of the motivations was assessed by Cronbach's $\alpha$. The reliability of pleasure was $.85(M=3.57, S D=.69)$, affection was .82 $(M=3.04, S D=.71)$, inclusion was $.82(M=3.20, S D=.76)$, escape was $.80(M=2.79$, 
$S D=.80)$, relaxation was $.82(M=3.20, S D=.72)$, and control was $.85(M=2.80, S D$ $=.79)$.

Loneliness. The UCLA loneliness scale (version 3) (Russell, 1996) was used to test respondents' chronic loneliness. Twenty items were measured by a 4-point Likert-scale ( $1=$ Never, $4=$ Always $)$ and the reliability of this scale was $.93(M=2.56, S D=0.65)$.

Life satisfaction. The Satisfaction with Life Scale (SWLS) (Diener, Emmons, Larsen, $\&$ Griffin, 1985) was used, and the five items were measured by a 5-point Likert-scale (1 $=$ strongly disagree $\sim 5=$ strongly agree $)$. The reliability was $.84(M=2.87, S D=0.69)$.

\section{RESULTS}

Hierarchical regression analysis was performed to examine the effects of Twitter users' perceived loneliness and life satisfaction on their ICMs. First, the demographic statistics were entered into the hierarchical regression model (see Model 1 in Tables 1 and 2), and then independent variables were entered (see Model 2 in Tables 1 and 2). Hypothesis 1-1 predicted that loneliness will negatively affect the motive of pleasure. As Table1 shows, individuals' loneliness was found to be negatively related with the motive of pleasure $(\beta=.29, p<.001)$, supporting the hypothesis $1-1$. The result shows that lonely people expect less to have a pleasant time while using Twitter. In addition, female Twitter users are more likely to communicate with others for the purpose of pleasure $(\beta$ $=.12, p<.05)$, and the user's age negatively affects it $(\beta=.11, p<.05)$. It can be inferred that female users and younger users tend to find more fun on Twitter. Hypothesis 1-2 expected negative effect of loneliness on the motive of affection. As expected, loneliness is inversely related with the motive of affection $(\beta=.22, p<.001)$, supporting hypothesis $1-2$. The result implies that lonely people are not eager to reveal what they are feeling or to exchange feelings with others on Twitter. However, loneliness was not found to be significantly associated with the communication motives of relaxation, inclusion, control, and escape, denying the hypotheses 1-3, 1-4, 1-5, and 1-6. For the motive of inclusion, female Twitter users were discovered to have a higher intention $(\beta=.12, p<.05)$, which explains that female users expect to feel included into a certain community by using Twitter. 
Table 1 Regressions of the Effects of Loneliness on ICMs of Twitter $(n=318)$

\begin{tabular}{|c|c|c|c|c|c|c|c|c|c|c|c|c|}
\hline \multirow[t]{2}{*}{ Motives } & \multicolumn{2}{|c|}{ Pleasure } & \multicolumn{2}{|c|}{ Affection } & \multicolumn{2}{|c|}{ Relaxation } & \multicolumn{2}{|c|}{ Inclusion } & \multicolumn{2}{|c|}{ Control } & \multicolumn{2}{|c|}{ Escape } \\
\hline & $\begin{array}{c}\text { Model } \\
1\end{array}$ & $\begin{array}{c}\text { Model } \\
2\end{array}$ & $\begin{array}{c}\text { Model } \\
1\end{array}$ & $\begin{array}{c}\text { Model } \\
2\end{array}$ & $\begin{array}{c}\text { Model } \\
1\end{array}$ & $\begin{array}{c}\text { Model } \\
2\end{array}$ & $\begin{array}{c}\text { Model } \\
1\end{array}$ & $\begin{array}{c}\text { Model } \\
2\end{array}$ & $\begin{array}{c}\text { Model } \\
1\end{array}$ & $\begin{array}{c}\text { Model } \\
2\end{array}$ & $\begin{array}{c}\text { Model } \\
1\end{array}$ & $\begin{array}{c}\text { Model } \\
2\end{array}$ \\
\hline Gender & .09 & $.12 *$ & -.01 & .01 & .10 & .10 & $.12 *$ & $.12^{*}$ & .06 & .07 & .07 & .06 \\
\hline Age & $-.14 *$ & $-.11 *$ & .04 & .06 & .02 & .03 & -.08 & -.08 & .09 & .10 & .04 & .03 \\
\hline Education & -.04 & -.06 & -.04 & -.05 & -.02 & -.02 & -.05 & -.05 & -.06 & -.06 & -.06 & -.06 \\
\hline Loneliness & & $\begin{array}{c}-.29 * * \\
*\end{array}$ & & $\begin{array}{c}-.22 * * \\
*\end{array}$ & & -.06 & & -.02 & & -.04 & & .09 \\
\hline $\begin{array}{c}\mathrm{R} 2 \\
(\Delta \mathrm{R} 2)\end{array}$ & .041 & $\begin{array}{c}.125 \\
(.084)\end{array}$ & .003 & $\begin{array}{c}.049 \\
(.046)\end{array}$ & .009 & $\begin{array}{c}.013 \\
(.004)\end{array}$ & .034 & $\begin{array}{c}.035 \\
(.001)\end{array}$ & .012 & $\begin{array}{c}.013 \\
(.001)\end{array}$ & .010 & $\begin{array}{c}.018 \\
(.008)\end{array}$ \\
\hline $\mathrm{F}$ & $\begin{array}{c}4.432 \\
* *\end{array}$ & $\begin{array}{l}11.22 \\
2 * * *\end{array}$ & .321 & $\begin{array}{c}4.068 \\
* *\end{array}$ & .997 & 1.060 & $\begin{array}{c}3.711 \\
*\end{array}$ & $\begin{array}{c}2.807 \\
*\end{array}$ & 1.253 & 1.053 & 1.006 & 1.444 \\
\hline
\end{tabular}

Note: $* p<.05, * * p<.01, * * * p<.001$

Hypothesis 2-1 supposed that life satisfaction will predict a higher level of the communication motive of pleasure (see Table 2 ), and the hypothesis was supported ( $\beta$ $=.19, p<.01)$. Twitter users who are satisfied with their lives may possibly use Twitter to have a pleasant time. Hypothesis 2-2 expected a positive effect of Twitter users' life satisfaction on their motive of affection. As the hypotheses indicated, life satisfaction of Twitter users was positively related with their communication motives of affection ( $\beta$ $=.34, p<.001)$. The result implies that people with a higher level of life satisfaction are more likely to exchange feelings with other users on Twitter. Hypothesis 2-3 predicted that life satisfaction affects a higher level of communication motive for relaxation, and the hypothesis was supported $(\beta=.24, p<.01)$. Along with this, female users were found to have a higher level of the relaxation motive $(\beta=.12, p<.05)$. Contrary to hypothesis $2-4$, life satisfaction was not significantly associated with individuals' communication motive of inclusion on Twitter $(\beta=.10, p>.05)$, but female users were more likely to have a higher intention for it $(\beta=.13, p<.05)$. Hypothesis $2-5$ predicted a negative effect of life satisfaction on Twitter users' communication motive of escape, but the hypothesis was rejected $(\beta=.11, p>.05)$. Hypothesis $2-6$ indicated that life satisfaction is related 
with a higher level of Twitter users' communication motive of control, and this hypothesis was supported $(\beta=.21, p<.001)$. It can be inferred that people who perceive life satisfaction may want to use Twitter in order to exert power over others.

Table 2 Regressions of the Effects of Life Satisfaction on ICMs of Twitter $(n=318)$

\begin{tabular}{|c|c|c|c|c|c|c|c|c|c|c|c|c|}
\hline \multirow[t]{2}{*}{ Motives } & \multicolumn{2}{|c|}{ Pleasure } & \multicolumn{2}{|c|}{ Affection } & \multicolumn{2}{|c|}{ Relaxation } & \multicolumn{2}{|c|}{ Inclusion } & \multicolumn{2}{|c|}{ Escape } & \multicolumn{2}{|c|}{ Control } \\
\hline & $\begin{array}{c}\text { Model } \\
1\end{array}$ & $\begin{array}{c}\text { Model } \\
2\end{array}$ & $\begin{array}{c}\text { Model } \\
1\end{array}$ & $\begin{array}{c}\text { Model } \\
2\end{array}$ & $\begin{array}{c}\text { Model } \\
1\end{array}$ & $\begin{array}{c}\text { Model } \\
2\end{array}$ & $\begin{array}{c}\text { Model } \\
1\end{array}$ & $\begin{array}{c}\text { Model } \\
2\end{array}$ & $\begin{array}{c}\text { Model } \\
1\end{array}$ & $\begin{array}{c}\text { Model } \\
2\end{array}$ & $\begin{array}{c}\text { Model } \\
1\end{array}$ & $\begin{array}{c}\text { Mode } \\
2\end{array}$ \\
\hline Gender & .09 & .11 & -.01 & .02 & .10 & $.12 *$ & $.12 *$ & $.13 *$ & .07 & .08 & .06 & .09 \\
\hline Age & $-.14 *$ & $-.14 *$ & .04 & .04 & .02 & .02 & -.08 & -.08 & .04 & .04 & .09 & .09 \\
\hline Education & -.04 & -.04 & -.04 & -.04 & -.02 & -.02 & -.05 & -.05 & -.06 & -.06 & -.06 & -.06 \\
\hline $\begin{array}{c}\text { Life } \\
\text { Satisfaction }\end{array}$ & & $.19 * *$ & & $\begin{array}{c}.34 * * \\
*\end{array}$ & & $\begin{array}{c}.24 * * \\
*\end{array}$ & & .10 & & .11 & & $\begin{array}{c}.21 * * \\
*\end{array}$ \\
\hline $\begin{array}{c}\mathrm{R} 2 \\
(\Delta \mathrm{R} 2)\end{array}$ & .041 & $\begin{array}{c}.076 \\
(.035)\end{array}$ & .003 & $\begin{array}{c}.116 \\
(.113)\end{array}$ & .009 & $\begin{array}{c}.066 \\
(.057)\end{array}$ & .034 & $\begin{array}{c}.043 \\
(.009)\end{array}$ & .010 & $\begin{array}{c}.022 \\
(.012)\end{array}$ & .012 & $\begin{array}{c}.057 \\
(.045)\end{array}$ \\
\hline $\mathrm{F}$ & $\begin{array}{c}4.432 \\
* *\end{array}$ & $\begin{array}{c}6.424 \\
* * *\end{array}$ & .321 & $\begin{array}{l}10.28 \\
0 * * *\end{array}$ & .997 & $\begin{array}{c}5.527 \\
* * *\end{array}$ & $\begin{array}{c}3.711 \\
*\end{array}$ & $\begin{array}{c}3.528 \\
* *\end{array}$ & 1.006 & 1.733 & 1.253 & $\begin{array}{c}4.745 \\
* *\end{array}$ \\
\hline
\end{tabular}

Note: $* p<.05, * * p<.01, * * * p<.001$

\section{DISCUSSION}

\section{Implications}

This study revealed how an individual's psychological situation in offline settings influenced the intention of communication on Twitter. The results indicate that people have different motives for online social interactions, depending on their social-psychological condition, loneliness, and life satisfaction. Thus, the characteristics of social interactions and interpersonal relationships maintained on Twitter can be explained.

According to the results, a person with higher chronic loneliness has less expectation of having a pleasant time and exchanging concerns toward others using Twitter. It is 
possible that lonely people do not often pursue a pleasant conversation and do not actively express their private feelings with other Twitter users. This indicates that lonely people do not regard Twitter as an alternative interactional space to compensate for their lack of a close social network. Moreover, since lonely people do not perceive any other communication motives, it can be inferred that their social activities remain as passive on Twitter as in offline settings. On the other hand, people with a higher level of life satisfaction have the intention to maintain interpersonal interactions on Twitter to gratify the motives of pleasure, affection, relaxation, and control. Individuals with life satisfaction look for a pleasant time and expect more frequent exchanges of their feelings concerning others on Twitter. At the same time, Twitter can be a stress-relieving place for them, and they are more likely to exert dominance over other users.

Implications regarding interpersonal communication motives on Twitter are as follows. First, although social interactions on Twitter have thrived recently, people who feel isolated from their social communities in real life do not seem to take advantage of Twitter to construct online-based social relationships. Previously, online communication that guaranteed anonymity could play a role to fill unsatisfied social interactions for the lonely (Amichai- Hamburger \& Ben-Artzi, 2003; Greenwood \& Long, 2009; Stepanikova, $\mathrm{Nie}, \& \mathrm{He}, 2010)$. However, recently introduced interpersonal communication media, such as Twitter, tend to combine the quality of offline and online interactions. People more often cultivate intimate relationships with friends on interpersonal media (Quan-Haase, 2007). A higher degree of interpersonal media use (e.g. Facebook) is closely related to stronger personal bonds (Steinfield, Ellison, \& Lampe, 2008). People who possess rich personal relationships can enhance them by being involved in mediated communication. Likewise, on Twitter, lonely people, by failing to compensate for the lack of social interactions, may not actively participate in communication. Hence, Twitter does not always provide people with a shelter for online-based intimate personal connections away from the offline world.

Second, people who are satisfied with their lives have more chances to manage and to improve the quality of interpersonal relationships efficiently. During ordinary daily life, a higher level of life satisfaction is related to the formation of positive relationships, especially for those who are motivated to feel affiliation and intimacy (Hofer, Busch, \& Kiessling, 2008). Similarly, for Twitter, as the findings of this study indicate, people who are more satisfied with their lives can maintain positive relationships with stronger motives for social interactions. Also, since the personal traits of extroversion and 
openness influence one's attainment of a higher level of life satisfaction (Hofer, Busch, \& Kiessling, 2008), it is possible that Twitter users with life satisfaction may more actively seek to interact with others, which is in turn reflected in their various interpersonal communication motives. Further, Twitter allows users with life satisfaction to have more opportunities to expand their interpersonal networks and to establish connections with various social communities.

The pattern of communication motives driven by Twitter users' social psychological status was similar with that in offline settings. It can be inferred that Twitter is not just a virtual space far from the real life but that it is also an extended place for individuals' offline social connections and interactions. Meanwhile, Twitter users' communication motives of inclusion and escape were not related with the state of loneliness or life satisfaction. This possibly implies that people do not lean on Twitter just to establish intimate personal connections or to find another online based environment for interactions. It might be inappropriate to view Twitter simply as a virtual space that contributes to enhancing the quality of insufficient personal relationships. Instead, people regard and then use Twitter as a social communication media through which they can freely exchange personal opinions and information with other members. In conclusion, Twitter has become another type of communication channel for both private conversation and public messages. The development of communication media has therefore widened the range of individuals' actual social interactions.

\section{Limitations and Suggestions for Further Research}

This study examines Twitter users' communication motives and the effects of their psychological conditions of loneliness and life satisfaction. However, it is also plausible that communication motives can change, depending on whom the users meet and with whom they have a conversation. For example, relational qualities with a close friend and a stranger may be differently related to a person's ICMs. Thus, the types of relationships can be taken into consideration to more elaborately support the links between psychological states and communication motives. Another limitation is that the current study adopted Twitter, just one of many interpersonal media channels that have emerged recently. Different SNSs may have diverse communication structures, and people may have different communication motives for each SNS. Future studies could analyze communication motives for various types of SNSs to generalize the description of the phenomena of mediated communication. 


\section{REFERENCES}

Acar, A. (2008). Antecedents and consequences of online social networking behavior: The case of facebook. Journal of Website Promotion, 3(1-2), 62-83. http://dx.doi.org/10.1080/15533610802052654.

Ali, F., \& Chamorro-Premuzic, T. (2010). The dark side of love and life satisfaction: Associations with intimate relationships, psychopathy and Machiavellianism. Personality and Individual Differences, 48(2), 228-233. http://dx.doi.org/10.1016/j.paid.2009.10.016.

Amichai-Hamburger, Y., \& Ben-Artzi, E. (2003). Loneliness and internet use. Computers in Human Behavior, 19(1), 71-80. http://dx.doi.org/10.1016/S0747-5632(02)00014-6.

Anderson, C.M., \& Martin, M.M. (1995). Why employees talk to coworkers and superiors: Motives, gender, and organizational satisfaction. Journal of Business Communication, 32(3), 249-266. http://dx.doi.org/10.1177/002194369503200303.

Arrindell, W.A., \& Luteijn, F. (2000). Similarity between intimate partners of personality traits as related to individual levels of satisfaction with life. Personality and Individual Differences, 28(4), 629-637. http://dx.doi.org/10.1016/S0191-8869(99)00125-7.

Barbato, C.A., Graham, E.E., \& Perse, E.M. (2003). Communicating in the family: An examination of the relationship of family communication climate and interpersonal communication motives. The Journal of Family Communication, 3(3), 123-148. http://dx.doi.org/10.1207/S15327698JFC0303_01.

Barbato, C.A., \& Perse, E.M. (1992). Interpersonal communication motives and life position of elders. Communication Research, 19(4), 516-531. http://dx.doi.org/ $10.1177 / 009365092019004007$.

Bardi, C.A., \& Brady, M.F. (2010). Why shy people use instant messaging: Loneliness and other motives. Computers in Human Behavior, 26(6), 1722-1726. http://dx.doi.org/10.1016/j.chb.2010.06.021.

Barnes, S.B. (2003). Computer-mediated communication: Human-to-human communication across the Internet. Boston, MA: Pearson Education Inc.

Birnholtz, J. (2010). Adopt, adapt, abandon: Understanding why some young adults start, and then stop, using instant messaging. Computers in Human Behavior, 26(6), 1427-1433. http://dx.doi.org/10.1016/j.chb.2010.04.021.

boyd, D.M. (2007, August 10). Friends, Friedsters, and Top 8: Writing community into 
being on social network sites. Fitst Monday, 11(12). Retrieved from http://firstmonday.org/issues/issue11_12/boyd/index.html.

boyd, D.M., \& Ellison, N.B. (2007). Social network sites: Definition, history, and scholarship. Journal of Computer-Mediated Communication, 13(1), 210-230. http://dx.doi.org/10.1111/j.1083-6101.2007.00393.x.

Bradburn, N.M. (1969). The structure of psychological well-being. Chicago: Aldine.

Campbell, A.J., Cumming S.R., \& Hughes, I. (2006). Internet use by the socially fearful: Addiction or therapy? CyberPsychology \& Behavior, 9(1), 69-81. http://dx.doi.org/10.1089/cpb.2006.9.69.

Civitci, N., \& Civitci, A. (2009). Self-esteem as mediator and moderator of the relationship between loneliness and life satisfaction in adolescents. Personality and Individual Differences, $47(8), \quad 954-958$. http://dx.doi.org/10.1016/j.paid.2009.07.022.

Correa, T., Hinsley, A.W., \& de Zuniga, H.G. (2010). Who interacts on the web?: The intersection of users' personality and social media use. Computers in Human Behavior, 26(2), 247-253. http://dx.doi.org/10.1016/j.chb.2009.09.003.

Desjarlais, M., \& Willowghby, T. (2010). A longitudinal study of the relation between adolescent boys and girls' computer use with friends and friendship quality: Support for the social compensation or the rich-get-richer hypotheses? Computers in Human Behavior, 26(5), 896-905. http://dx.doi.org/10.1016/j.chb.2010.02.004.

Diener, E. (2009). Subjective well-being. In Ed Diener (Ed.). The science of well-being: The collected works of Ed Diener (pp. 11-58). New York: Springer. http://dx.doi.org/10.1007/978-90-481-2350-6_2.

Diener, E., Emmons, R.A., Larsen, R.J., \& Griffin, S. (1985). The satisfaction with life scale. Journal of Personality Assessment, 49(1), 71-75. http://dx.doi.org/10.1207/s15327752jpa4901_13.

Diener, E., Oishi, S., \& Lucas, R.E. (2003). Personality, culture, and subjective well-being: Emotional and cognitive evaluation of life. Annual Review of Psychology, 54(1), 403-425. http://dx.doi.org/10.1146/annurev.psych.54.101601.145056.

Diener, E., \& Suh, E.M. (1998). Subjective well-being and age: an international analysis. In K. Warner Schaie \& M. Powell Lawton (Eds.), (pp. 304-324) Annual Review of Gerontology and geriatrics. New York: Springer Publishing Company.

Downs, V.C., \& Javidi, M. (1990). Linking communication motives to loneliness in the 
lives of older adults: An empirical test of interpersonal needs and gratifications. Journal of Applied Communication Research, 18(1), 32-48. http://dx.doi.org/10.1080/00909889009360313.

Downs, V.C., Javidi, M., \& Nussbaum, J.F. (1987). Communication apprehension and loneliness in older adults: An empirical test to socio-environmental theory. Communication Research Reports, 4(2), 73-80.

Edwards, N.J., \& Klemmack, D. L. (1973). Correlates of life satisfaction: A re-examination. Journal of Gerontology, 28(4), 497-502. http://dx.doi.org/10.1093/geronj/28.4.497.

Fogle, L.M., Huebner, E., \& Laughlin, J.E. (2002). The relationship between temperament and life satisfaction in early adolescence: Cognitive and behavioral mediation models. Journal of Happiness Studies, 3(4), 373-392. http://dx.doi.org/10.1023/A:1021883830847.

Graham, E.E., Barbato, C.A., \& Perse, E.M. (1993). The interpersonal communication motives model. Communication Quarterly, 41(2), 172-186. http://dx.doi.org/10.1080/01463379309369877.

Greenwood, D.N., \& Long, C.R. (2009). Psychological predictors of media involvement: Solitude experiences and the need to belong. Communication Research, 36(5), 637-654. http://dx.doi.org/10.1177/0093650209338906.

Gross, E.F., Juvonen, J., \& Gable, S.L. (2002). Internet use and well-being in adolescence. Journal of Social Issues, 58(1), 75-90. http://dx.doi.org/10.1111/1540-4560.00249.

Gilman, R., \& Huebner, E.S. (2006). Characteristics of adolescents who report very high life satisfaction. Journal of Youth and Adolescence, 35(3), 293-301. http://dx.doi.org/10.1007/s10964-006-9036-7.

Hofer, J., Busch, H., \& Kiessling, F. (2008). Individual pathways to life satisfaction: The significance of traits and motives. Journal of Happiness Studies, 9(4), 503-520. http://dx.doi.org/10.1007/s10902-007-9086-x.

Hopf, T., \& Colby, N. (1992). The relationship between interpersonal communication apprehension and self-efficacy. Communication Research Reports, 9(2), 131-135. http://dx.doi.org/10.1080/08824099209359905.

Hosman, L.A. (1991). The relationship among need for privacy, loneliness, conversational sensitivity, and interpersonal communication motives. $\begin{array}{lll}\text { Communication } & \text { Reports, } & \text { 73-80. }\end{array}$ http://dx.doi.org/10.1080/08934219109367527. 
Huberman, B.A., Romero, D.M., \& Wu, F. (2008). Social networks that matter: Twitter under the microscope. First Monday, 14(1), 1-9. http://dx.doi.org/10.5210/fm.v14i1.2317.

Hughes, A.L., \& Palen, L. (2009). Twitter adoption and use in mass convergence and emergency events. International Journal of Emergency Management, 6(3), 248-260. http://dx.doi.org/10.1504/IJEM.2009.031564.

Hullman, G.A. (2004). Interpersonal communication motives and message design logic: Exploring their interaction on perceptions of competence. Communication Monographs, 71(2), 208-225. http://dx.doi.org/10.1080/0363775042000250411.

Kahneman, D., \& Krueger, A.B. (2006). Developments in the measurement of subjective well-being. Journal of Economic Perspectives, 20(3), 3-24. http://dx.doi.org/10.1257/089533006776526030.

Katz, E., Blumler, J.G., \& Gurevitch, M. (1974). Utilization of mass communication by the individual. In J.G. Blumler \& E. Katz (Eds.), The uses of mass communications: Current perspectives on gratifications research (pp. 19-32). Beverly Hills: Sage.

Knapp, M.R.J. (1976). Predicting the dimensions of life satisfaction. Journal of Gerontology, 31(5), 595-604. http://dx.doi.org/10.1093/geronj/31.5.595.

Kraut, R., Kiesler, S., Boneva, B., Cummings, J., Helgeson, V., \& Crawford, A. (2002). Internet paradox revisited. Journal of Social Issues, 58(1), 49-74. http://dx.doi.org/10.1111/1540-4560.00248.

Lent, R.W., Singley, D., Sheu, H.-B., Gainor, K.A., Brenner, B.R., Treistman, D., \& Ades, L. (2005). Social cognitive predictors of domain and life satisfaction: Exploring the theoretical precursors of subjective wellbeing. Journal of Counseling Psychology, 52(3), 429-442. http://dx.doi.org/10.1037/0022-0167.52.3.429.

Luszczynska, A., Scholz, U., \& Schwarzer, R. (2005). The general self efficacy scale: Multicultural validation studies. The Journal of Psychology, 139(5), 439- 457. http://dx.doi.org/10.3200/JRLP.139.5.439-457.

Makoul, G., \& Roloff, M. E. (1998). The role of efficacy and outcome expectations in the decision to withhold relational complaints. Communication Research, 25(1), 5-29. http://dx.doi.org/10.1177/009365098025001001.

Marangoni, C., \& Ickes, W. (1989). Loneliness: A theoretical review with implications for measurement. Journal of Social and Personal Relationships, 6(1), 93-128. http://dx.doi.org/10.1177/026540758900600107.

Martin, M.M., Myers, S.A., \& Mottet, T.P. (1999). Student motives for communicating 
International Journal of Cyber Society and Education $\quad 67$

with their instructors. Communication Education, 48(2), 155-164. http://dx.doi.org/10.1080/03634529909379163.

Mesch, G.S. (2001). Social relationships and Internet use among adolescents in Israel. $\begin{array}{llll}\text { Social Science } & \text { Quarterly, } & \text { 329-339. }\end{array}$ http://dx.doi.org/10.1111/0038-4941.00026.

Morahan-Martin, J., \& Schumacher, P. (2003). Loneliness and social uses of the Internet. Computers in Human Behavior, 19(6), 659-671. http://dx.doi.org/10.1016/S0747-5632(03)00040-2.

Naaman, N., Boase, J., \& Lai, C. (2010). Is it really about me? Message content in social awareness streams. In J.C. Tang (Ed.), Prodeedings of the 2010 ACM Conference on Computer Supported Cooperative Work (pp. 189-192). New York, USA: ACM Press. http://dx.doi.org/10.1145/1718918.1718953.

Neto, F., \& Barros, J. (2000). Psychosocial concomitants of loneliness among students Cape Verde and Portugal. The Journal of Psychology, 134(5), 503-514. http://dx.doi.org/10.1080/00223980009598232.

Papacharissi, Z., \& Rubin, A.M. (2000). Predictors of Internet use. Journal of Broadcasting \& Electronic Media, 44(20), 175-196. http://dx.doi.org/10.1207/s15506878jobem4402_2.

Paulsel, M.L., \& Mottet, T.P. (2004). Interpersonal communication motives: A communibiological perspective. Communication Quarter, 52(2), 182-195. http://dx.doi.org/10.1080/01463370409370189.

Perlman, D., \& Peplau, L.A. (1981). Towards a social psychology of loneliness. In R. Gilmour \& S. Duck (Eds.), Personal relationships 3: Personal relationships in disorder (pp. 31-56). London: Academic Press.

Peplau, L.A., \& Perlman, D. (1982). Perspectives on loneliness. In L.A. Peplau \& D. Perlman (Eds.), Loneliness: A sourcebook of current theory, research, and therapy (pp. 1-18). New York: Wiley-Interscience.

Perse, E.M., \& Rubin, A.M. (1990). Chronic loneliness and media use. Journal of Broadcasting and Electronic Media, 34(1), 37-53. http://dx.doi.org/10.1080/08838159009386724.

Peter, J., \& Valkenburg, P.M. (2006). Research Note: Individual differences in perceptions of Internet communication. European Journal of Communication, 21(2), 213-226. http://dx.doi.org/10.1177/0267323105064046.

Prinstein, M.J., Boergers, J., \& Vernberg, E.M. (2001). Overt and relational aggression in 
adolescents: Social-psychological adjustment of aggressors and victims. Journal of $\begin{array}{llll}\text { Clinical Child } & \text { Psychology, }\end{array}$ http://dx.doi.org/10.1207/S15374424JCCP3004_05.

Quan-Haase, A. (2007). College students' local and distance communication: Blending online and offline media. Information, Communication and Society, 10(5), 671-693.

Quan-Haase, A., \& Young, A.L. (2010). Uses and gratifications of social media: A comparison of facebook and instant messaging. Bulletin of Science, Technology, \& Society, 30(5), 350-361. http://dx.doi.org/10.1177/0270467610380009.

Raacke, J., \& Bonds-Raacke, J. (2008). MySpace and facebook: Applying the uses and gratifications theory to exploring friend-networking sites. Cyberpsychology \& Behavior, 11(2), 169-174. http://dx.doi.org/10.1089/cpb.2007.0056.

Rau, P.P., Gao, Q., \& Ding, Y. (2008). Relationship between the level of intimacy and lurking in online social network services. Computers in Human Behaviors, 24(6), 2757-2770. http://dx.doi.org/10.1016/j.chb.2008.04.001.

Rubin, R.B., Perse, E.M., \& Barbato, C.A. (1988). Conceptualization and measurement of interpersonal communication motives. Human Communication Research, 14(4), 602-628. http://dx.doi.org/10.1111/j.1468-2958.1988.tb00169.x.

Rubin, R.B., \& Rubin, A.M. (1992). Antecedents of interpersonal communication motivation. Communication Quarterly, 40(3), 305-317. http://dx.doi.org/10.1080/01463379209369845.

Rubin, A.M., \& Windahl, S. (1986). The uses and dependency model of mass communication. Critical Studies in Mass Communication, 3(2), 184-199. http://dx.doi.org/10.1080/15295039609366643.

Russell, D.W. (1996). UCLA loneliness scale (Version 3): reliability, validity, and factor structure. Journal of Personality Assessment, 66(1), 20-40. http://dx.doi.org/10.1207/s15327752jpa6601_2.

Schutz, W.C. (1966). The interpersonal underworld. Palo Alto, CA: Science and Behavior Books.

Shaw, L.H., \& Gant, L.M. (2002). In defense of the Internet: The relationship between internet communication and depression, loneliness, self-esteem, and perceived social support. CyberPsychology $\&$ Behavior, 5(2), 157-171. http://dx.doi.org/10.1089/109493102753770552.

Steinfield, C., Ellison, N.B., \& Lampe, C. (2008). Social capital, self-esteem, and use of online social network sites: A longitudinal analysis. Journal of Applied 
$\begin{array}{lll}\text { Developmental } & \text { Psychology, } & \text { 29(6), }\end{array}$ http://dx.doi.org/10.1016/j.appdev.2008.07.002 .

Step, M.M., \& Finucane, M.O. (2002). Interpersonal communication motives in everyday interactions. Communication Quarterly, 50(1), 93-109. http://dx.doi.org/10.1080/01463370209385648.

Stepanikova, I., Nie, N.H., \& He, X. (2010). Time on the Internet at home, loneliness, and life satisfaction: Evidence from panel time-diary data. Computers in Human Behavior, 26(3), 329-338. http://dx.doi.org/10.1016/j.chb.2009.11.002.

Subrahmanyam, K., Reich, S.M., Waechter, N., \& Espinoza, G. (2008). Online and offline social networks: Use of social network sites by emerging adults. Journal of Applied Developmental Psychology, 29(6), 420-433. http://dx.doi.org/10.1016/j.appdev.2008.07.003.

Valkenburg, P.M., Schouten, A.P., \& Peter, J. (2005). Adolescents' identity experiments on the Internet. New Media and Society, 7(3), 383-402.

Wan, C.K., Jaccard, J., \& Ramey, S.L. (1996). The relationship between social support and life satisfaction as a function of family structure. Journal of Marriage \& Family, 58(2), 502-513. http://dx.doi.org/10.2307/353513.

Wang, Y., \& Sun, S. (2009). Examining Chinese students' Internet use and cross-cultural adaptation: Does loneliness speak much? Asian Journal of Communication, 19(1), 80-96. http://dx.doi.org/10.1080/01292980802618494.

Westmyer, S.A., Dicioccio, R.L., \& Rubin, R.B. (1998). Appropriateness and effectiveness of communication channels in competent interpersonal communication. Journal of Communication, 48(3), 27-48. http://dx.doi.org/10.1093/joc/48.3.27.

Young, J. (2008, December 1). Forget e-mail: New Messaging Service has Students and Professors a twitter. The Chronicle of Higher Education, 54(25). Retrieved from http://hronicle.com/free/v54/i25/25a01501.htm.

Zakahi, W.R. (1986). The effects of loneliness on perception of interaction: A cross-lag panel study. Communication Research Reports, 3(1), 94-99.

Zywica, J. \& Danowski, J. (2008). The faces of facebookers: Investigating social enhancement and social compensation hypotheses: Predicting facebook and offline popularity from sociability and self-esteem, and mapping the meanings of popularity with semantic networks. Journal of Computer-Mediated Communication, 14(1), 1-38. http://dx.doi.org/10.1111/j.1083-6101.2008.01429.x. 
International Journal of Cyber Society and Education 70 